\begin{tabular}{cc|c}
\hline Tar. Bil. Der. & Tarm Bilimleri Dergisi & Journal of Agricultural Sciences \\
& $\begin{array}{c}\text { Dergi web sayfası: } \\
\text { www.agri.ankara.edu.tr/dergi }\end{array}$ & Journal homepage: \\
& www.agri.ankara.edu.tr/journal
\end{tabular}

\title{
Seed Quality of Oilseed Rape Varieties with Different Size and Colors After Three and Fifteen Months Storage
}

\author{
Jasmina KNEŽEVIĆa ${ }^{a}$, Dalibor TOMIIĆc, Dražen JOVANOVIĆd ${ }^{\text {, Nadica TMUŠIĆ }}{ }^{a}$, Ratibor ŠTRBANOVIĆb \\ Dobrivoj POŠTíć , Rade STANISAVLJEVIĆC \\ ${ }^{a}$ University of Priština, Faculty of Agriculture, Kopaonička bb, 38219, Lešak, SERBIA \\ ${ }^{b}$ Institute for Plant Protection and Environment, Teodora Drajzera 9, 11000, Belgrade, SERBIA \\ ${ }^{c}$ University of Kragujevac, Faculty of Agronomy, Cara Dušana 34, 32000, Čačak, SERBIA \\ ${ }^{d}$ University of Bijeijina in Bijeijina, Faculty of Health Studies, BB, 76300, Bijeljina, Republic of Srpska, BOSNIA and HERZEGOVINA
}

\section{ARTICLE INFO}

Research Article

Corresponding Author: Rade STANİSAVLJEVİĆ, E-mail: stanisavljevicrade@gmail.com, Tel: +381 (11) 2660049

Received: 11 July 2018, Received in Revised Form: 17 August 2018, Accepted: 04 October 2018

\begin{abstract}
During two years, germinability and initial growth of seedling of nine foreign varieties and four domestic varieties were studied. The seed is grouped by size (small, medium and large), color (dark transitional and light color of seed coat). Then it was preserved and at three and fifteen months of age in the laboratory and in the field, germinability, dormant seed and growth of shoot and radicle root were examined. In addition to the age, other factors (variety, size, color, period of storage) influenced significantly ( $\mathrm{P} \geq 0.05$ to $\mathrm{P} \geq 0.00$ ) on seed germinability and growth of seedling.

Higher germinability is achieved from large seeds up to $3.6 \%$. Depending on the seed coat color, the germinability varied to $11 \%$. The seed coat color has had a high impact on maintaining germinability for fifteen months. Seeds with darker coat have also shown higher potential for storage and use in subsequent seeding periods, as determined by the application of the aging test on seed. Significant interdependence (r) was obtained between the germinability test and the growth of seedling in laboratory conditions and in field conditions. Between the germinability and the growth of the shoot and the root, a significant interdependence was established, depending on the varieties ( $\mathrm{P} \geq 0.05$ to $\mathrm{P} \geq 0.00$ ).

Keywords: Age; Dormancy; Germinability; Seed; Seedlings
\end{abstract}

(C) Ankara Üniversitesi Ziraat Fakültesi

\section{Introduction}

Oilseed rape (Brassica napus L.) is the most important source of vegetable oil in Europe, the second most important in the world, with the production of over 35 million hectares (http:// faostat.fao.rg/). The tendency to increase the area of this agricultural crop is also recorded in Serbia (Statistical Yearbook of Serbia 2017). In addition to growing it for oil, this plant species is also cultivated for green fodder and green fertilizing, but on smaller areas. By planting this plant species in the autumn period (August-September), it often happens that the crop does not sprout simultaneously, after that period the autumn frosts soon occur causing some seedling to freeze and planted crops do not have the required number of plants. For this situation, the 
reasons may be numerous such as insufficient and untimely rainfall, sowing in poorly prepared land in combination with low precipitation or deep sowing, etc. However, the seed that is used to plant crops can be the cause of uneven germinability. In open market countries like Serbia, farmers are offered a variety of varieties. Our producers have reported that the offered seed differs by color, size andage and that this may be the reason for the non-realization of the projected number of plants. On the other hand, it is known that in different cultivars, in a certain percentage, there will be dormant seeds that will germinate after the time of maturation and give a normal seedling, but the delayed germination and underdeveloped seedling in the period of stronger minus temperatures can be destroyed. According to Adkinset al (2002), through the process of breeding of agriculturally important species, dormant seeds have decreased or completely lost. On the other hand, there are no significant differences in species such as forage and ornamental grasses between sorts and populations from the natural environment in the presence of dormant seeds (Stanisavljević et al 2012).

Seed size is an important indicator of the physical quality of seeds.In research on different plant species, there are very contradictory results on the relationship between seed size and germinability, and the initial growth of seedlings. For example, in the species, Triticum aestivum according to Zareian et al (2013) the size of the seed does not have a significant effect on seed germinability, in contrast to Kakhki et al (2008) indicating a significantly higher germinability of large seed.The seed coat is an outer shell of each harvested seed and in many species, it differs in color. On the seed of the genus Brassica, this is very pronounced (Rahman \& McVetty 2011)
After the release of seeds from dormancy, maximum germinability is achieved, and then the aging process begins, which inevitably results in reduced germinability, which depends on the plant species, the way of keeping the seed, etc. (Bewley 1997).

Therefore, the aim of these trials was to determine the agronomic value of seeds of domestic and foreign varieties and/or rapeseed hybrids of different size, color and age. It also recommends to producers that the seed is better for use. And it points to the growers the association of seed color and bulk with seed germinability and the initial growth of seedlings end thepossibility of improvement of management by cropping.

\section{Material and Methods}

\subsection{Materials}

During 2015 A1 and 2016 A2 (Table 1) (Factor of years-A) from the vicinity of the city of Pančevo $\left(44^{\circ} 52^{\prime} \mathrm{N}, 20^{\circ} 41^{\prime} \mathrm{E}\right.$ and $74 \mathrm{~m}$ asl), the seed of nine winter hybrid oilseed rape varieties (Brassica napus) were taken: RWA Prima (B1), Euralis neptune (B2), Bayer (B3), Umberto (B4), Travijat (B5), Balgira (B6), RWA Faxtor (B7), KVS Gordon (B8), Hybrirock (B9) and, four domestic varieties: Jasna (B10), Slavica (B11), Zlatna (B12), Zorica (B13) of oilseed rape (www.nsseme.com/ about/?opt=oilcrops\&cat=about) (the variety factorB). Of all varieties according to the mass of 1000 seeds, the seeds are grouped into three sizes; small to $3.8 \mathrm{~g} \mathrm{C} 1$, medium $3.8 \mathrm{~g}$ up to $4.1 \mathrm{~g} \mathrm{C} 2$, and a large of more than $4.1 \mathrm{~g} \mathrm{C} 3$, the seed size factor-C, (Stanisavljević et al 2018). Also from each variety, the seeds are grouped by color: light (D1), transient (D2) and dark (D3), the color factor (D). They were

Table 1- Seed harvesting time in seed germination incubator (experiment I) and containers (experiment II)

\begin{tabular}{lcc}
\hline Day month year, harvesting seed & 25 June 2015 & 6 July 2016 \\
\hline & 22 September2015 age of seeds about & 29 September 2016 age of seeds about \\
Day, month, year for an & 3 months-E1 & 3 months-E1 \\
experimentI and experiment II & 16 September 2016 age of seeds about & 19 September 2017 age of seeds about \\
& 15 months-E2 & 15 months-E2 \\
\hline
\end{tabular}


placed in double-layered paper bags and stored in warehouse conditions without controlling the temperature and humidity of the air. After seed storage for three months E1 (autumn sowing period) and seed storage of fifteen months E2 (autumn sowing period in the next year) the seed was divided into three subsamples from which III experiments were performed.

\subsection{Experiment $I$}

From the first subsample examined in laboratory conditions were: germination, dormancy seeds and the growth of seedlings (the shoot in $\mathrm{cm}$ and radicle (root) in $\mathrm{cm}$ ). Seeds were chilled for five days at $5{ }^{\circ} \mathrm{C}$ and were exposed in the seed germination chambers to alternating temperatures $20 / 30{ }^{\circ} \mathrm{C}, 8 \mathrm{~h}$ in light (1250 lux) during 16 hours in the dark. Seed germination (\%) and dormancy seeds (\%) were determined for each of the factors (four replicates of 100 seeds on filter paper); final count was done on the $14^{\text {th }}$ day (ISTA 2016.). The tetrazolium test was applied on dormancy seeds in order to separate dead seeds from hard ones (ISTA 2008). In addition, seedling vigor was determined in germinated seeds: the length of the shoot $(\mathrm{cm})$, the length of the root (cm), (Stanisavljević et al 2011).

\subsection{Experiment II}

From the second sub-sample of the seed according to complete randomized block design, it was sown at optimum depth in containers filled with soil in which the optimal soil moisture content was maintained in the period after the three-autumn sowing (E1) and after fifteen months-autumn seeding next year (E2). After 12 days, the seedlings (germination \%) were washed out from the soil and each measured (shoot in $\mathrm{cm}$ and root in $\mathrm{cm}$ ).

\subsection{Experiment III}

From the third sub-sample, the seed was subjected to the aging test: of all the varieties (B1-B13) of the seed of different sizes (C1-C3), color (D1-D3) and the age of three months (E1), fifteen months (E2) and immediately after gathering (E0): in four replications $/ 100$ seeds each, the seed was placed in dishes and in a water bath at a temperature of $41{ }^{\circ} \mathrm{C}$ and a relative air humidity of $100 \%$ for 72 hours which is optimal for evaluating the seed of the rapeseed (Komba et al 2006).

\subsection{Statistical analysis}

Data from all experiments are mean values. Measurements were performed on three replicates \pm standard deviation (SD). The obtained results were subjected to variance analysis (ANOVA; F test). Tukey multiplex test $(\mathrm{P} \geq 0.05)$ was used to assess the impact of the mean of treatment. For the interdependence between the Experiments I and II (Germinability, Shoot andRoot growth), the simple correlation coefficients (r) were calculated. Germination data and dormancy percentages were arcsine transformed [sqr (x/100)] before the variance analysis. Minitab 16.1.0 software was used for data processing.

\section{Results and Discussion}

\subsection{The influence of factors}

Using ANOVA, F test we found that the effect of the years did not significantly affect the studied properties. This can be explained by similar climatic conditions in which seed maturation (not shown) occurred. Therefore, in the further presentation of the results, the average from the two tested years was taken. The other factors $(\mathrm{B}, \mathrm{C}, \mathrm{D}, \mathrm{E})$ affected significantly $(\mathrm{P} \geq 0.05$ to $\mathrm{P} \geq 0.00)$ the germinability and seedling growth (not shown).

\subsection{Experiment $I$}

Generally for the average of all varieties, from large seed (C3) in relation to small seed (C1), higher germinability was achieved by $3.6 \%$ after three months of seed storage (E1). After fifteen months for germinability, the same tendency was found with a difference of $2.9 \%$ (Table 2). The greater difference in germinability was achieved by the influence of varieties $(\mathrm{C} 14 \%$, and $5 \%$ for $\mathrm{C} 2$ and C3) after three months (E1) and, for 5\% from seed $\mathrm{C} 1$, and $7 \%$ from seeds $\mathrm{C} 2$ and $\mathrm{C} 3$ in the period $\mathrm{E} 2$. The same tendency was observed for the growth of 
the shoot $(\mathrm{C} 37.25 \mathrm{~cm} \mathrm{C1} 6.67 \mathrm{~cm}$, with a difference of $0.58 \mathrm{~cm})$ and root $(\mathrm{C} 36.55 \mathrm{~cm} \mathrm{C} 15.70 \mathrm{~cm}$, with a difference of $0.85 \mathrm{~cm}$ ) and $\mathrm{E} 1$ period and in $\mathrm{E} 2$ shoot (C3 $7.17 \mathrm{~cm} \mathrm{C1} 6.62 \mathrm{~cm}$ with a difference of $0.57 \mathrm{~cm})$, and root $(\mathrm{C} 36.52 \mathrm{~cm} \mathrm{C} 15.70 \mathrm{~cm})$ with a difference of $0.82 \mathrm{~cm}$.

Depending on the seed volume in the E1 period, the difference in the percentage of dormant seeds was only $0.5 \%$, and after fifteen months $0.1 \%$ (the average of all varieties) with variation due to the influence of varieties by $4 \% \mathrm{C} 1,5 \% \mathrm{C} 2$, and $3 \%$ $\mathrm{C} 3$ in the $\mathrm{E} 1$ period. After fifteen months, dormant seeds decreased $>1 \%$, which affected a very similar germinability with an E1 period (Table 2).

For germinability between domestic varieties and foreign (hybrid varieties), a similar variability for the E1 period was found. After fifteen months (E2) the seed of all sizes of domestic varieties, had minimal higher variability $(\mathrm{C} 1 \mathrm{CV}=3.27 \%$ to $\mathrm{C} 3$ $\mathrm{CV}=3.45 \%)$ from foreign varieties $(\mathrm{C} 2 \mathrm{CV}=1.59 \%$ to $\mathrm{C} 3 \mathrm{CV}=1.80 \%$ ). For the growth of the shoot foreign varieties showed higher variability in both periods of testing (E1 and E2), while there was no clear legality for the growth of the root (Table 2).

Depending on the seed coat color, germinability varied by $4 \%$ (D1 92\% to D3 88\%) in the E1 period and by $9 \%$ (D3 95 to $84 \%$ D1) in the E2 period. However, germinability from light seed in the E2 period decreased by $8 \%$ compared to E1 period whereas as contrast dark seed germinability in the E2 period increased by $7 \%$ in relation to the E1 period.

The difference in germinability caused by the influence of the variety in the E1 period ranged from $4 \%$ (D3) to $7 \%$ (D1) and in the E2 period from $6 \%$ (D3) to $8 \%(\mathrm{D} 1, \mathrm{D} 2)$ (Table 3). The germinability of domestic varieties of all colours had higher variability $(\mathrm{CV}=1.59 \% \mathrm{D} 3 \mathrm{E} 1$ to $\mathrm{CV}=3.56 \% \mathrm{D} 1$ $\mathrm{E} 2)$ from foreign $(\mathrm{CV}=2.43 \% \mathrm{D} 3 \mathrm{E} 1$ to $\mathrm{CV}=5.20 \%$ D2 E2), while there was no clear legality in the growth of seedling (Table 3 ).

From the group of light seeds (D1) $2.6 \%$ of dormant seeds were found and from dark (D3) 9.3\% in the E1 period. After fifteen months (E1) from the D1 group, there was no dormant seed, while from D3 $0.8 \%$ were found whereas B4 had 3\% of dormant seed (Table 3).

\subsection{Experiment II}

In general between the germinability and the seedling growth (the shoot+root), significant correlative interdependence but of different strength (varieties $\mathrm{B} 2, \mathrm{P} \geq 0.001$ to $\mathrm{B} 7$ and $\mathrm{B} 2 \mathrm{P} \geq 0.05$ ) was established in all varieties (Table 4).

\subsection{Experiment III}

The application of the aging test on all varieties has shown that darker seeds have shown a stronger vitality which indicates a higher potential for storing darker seeds (Table 6). On the other side, the aging test did not detect the differences between the varieties in the potentials for use in the following period, not even at one factor $(\mathrm{C}, \mathrm{D}, \mathrm{E})$, but clearly detected differences between seeds of different ages in all varieties (Table 5 and 6). According to Avcret al (2017), the results showed that there was a significant difference in seed vigor of sorghum cultivars grown at same ecological conditions end the significant relationship between accelerated aging and laboratory emergence $(\mathrm{r}=0.967)$.

After sowing in containers in the E1 and E2 period in field conditions on the $12^{\text {th }}$ day the seedlings were harvested from the humid soil, which represented field germinability. As in laboratory conditions (Experiment I), the growth of seedlings was measured. By calculating the correlation coefficient (r) between the germinability and the growth of seedlings, significant interdependence was established in all varieties as follows: varieties $\mathrm{B} 8, \mathrm{~B} 10, \mathrm{~B} 12 ; \mathrm{P} \geq 0.001$ to variety $\mathrm{B} 7 ; \mathrm{P} \geq 0.05$ (Table 4).

Germination of seeds is a complex physiologicalbiochemical process controlled by many mechanisms (Bewley 1997; Liu et al 2013; Gu et al 2016).From an agricultural point of view, high germinability generally means, the realization of the projected number of plants with a smaller amount of seed, i.e., cheaper cropping. The second requirement for agriculture is as strong as possible the initial growth 


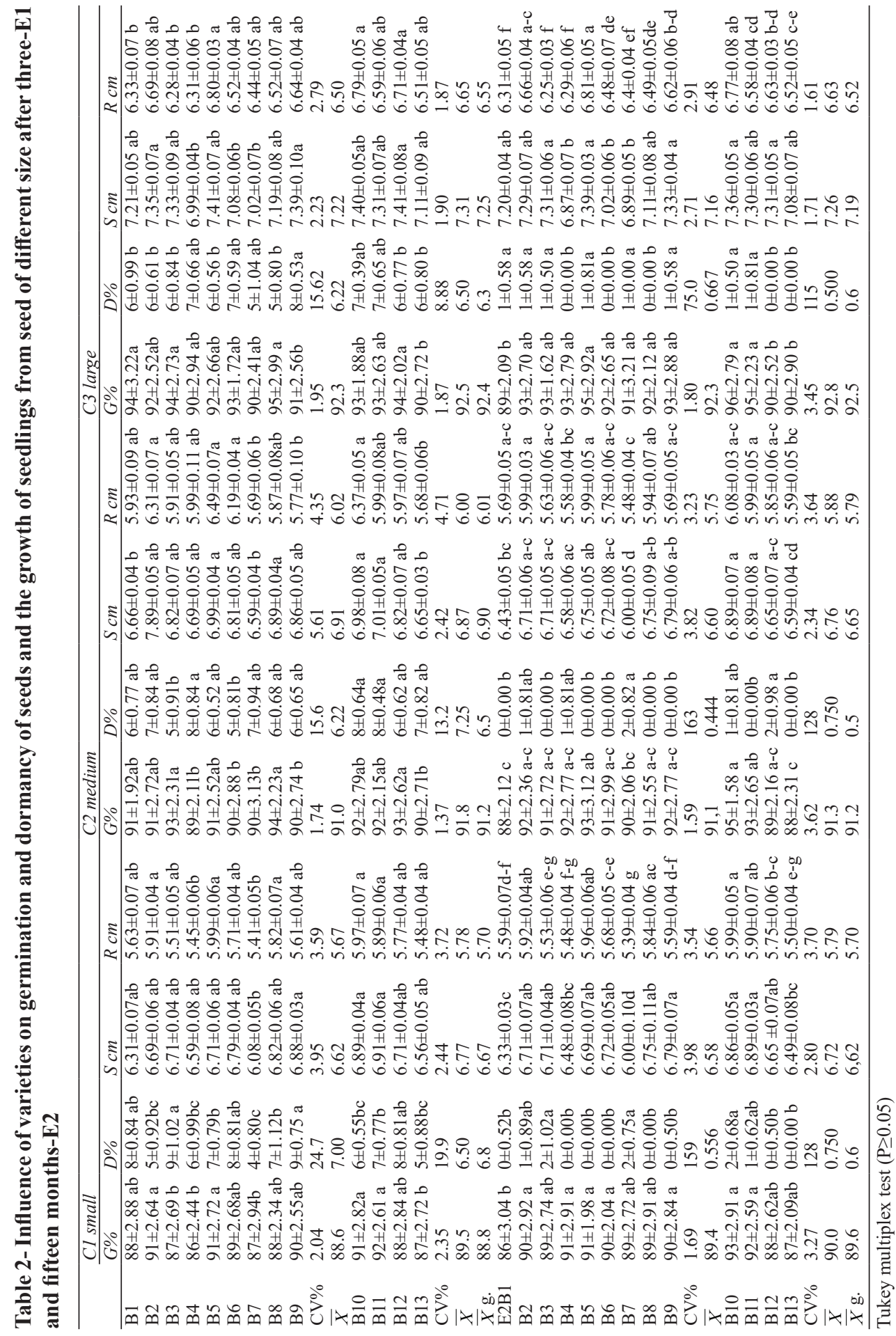




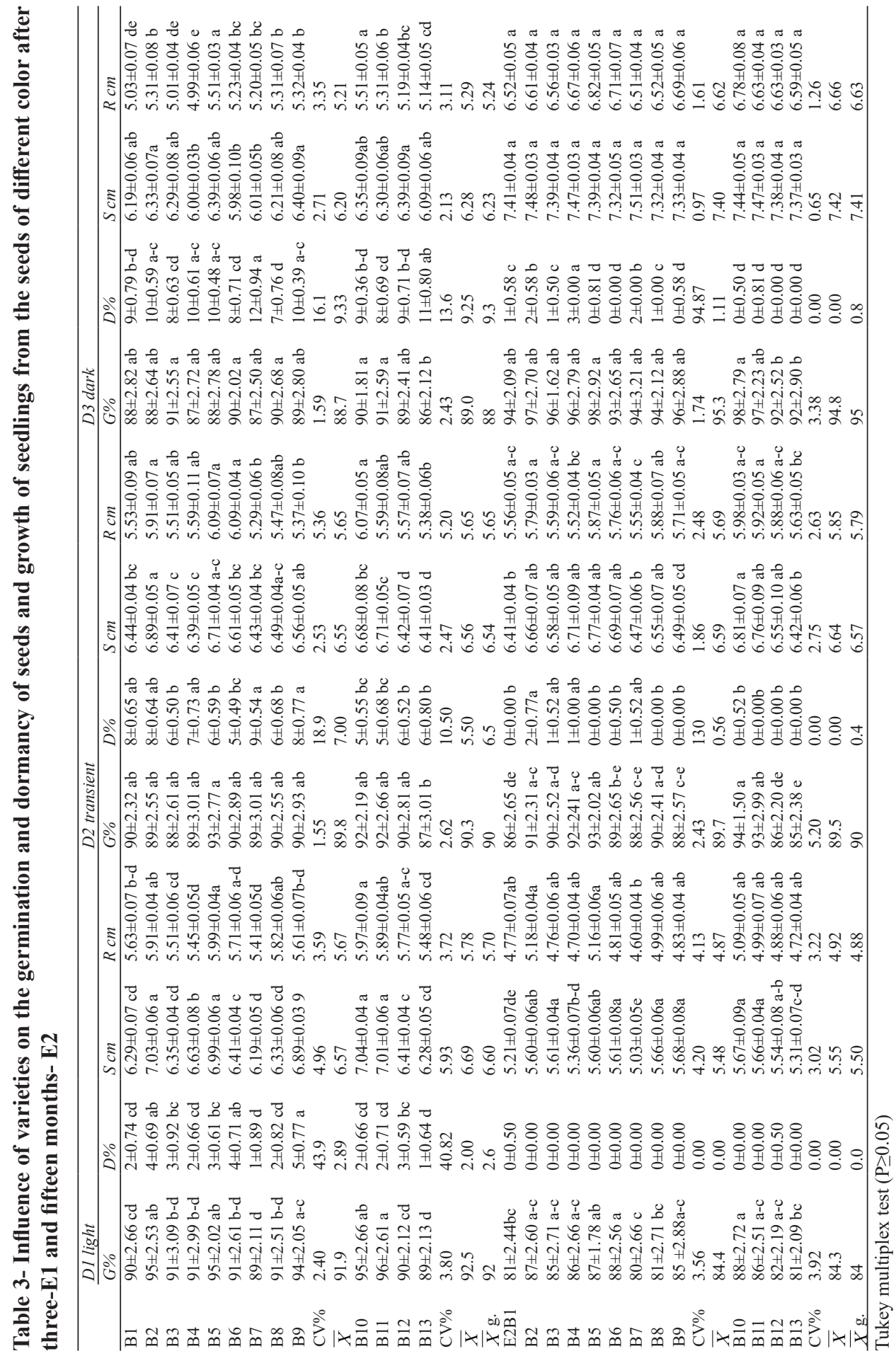


Table 4- Coefficients of simple correlations (r) between germination and growth of seedling (stem $\mathrm{cm}$, root $\mathrm{cm})$ of oilseed rape varieties $(\mathrm{n}=36)$

\begin{tabular}{lll}
\hline Variety & $\begin{array}{l}\text { Stem } \\
(\mathrm{cm})\end{array}$ & $\begin{array}{l}\text { Root } \\
(\mathrm{cm})\end{array}$ \\
\hline $\mathrm{B} 1$ & $*$ & $* *$ \\
$\mathrm{~B} 2$ & $* * *$ & $* * *$ \\
$\mathrm{~B} 3$ & $* *$ & $*$ \\
$\mathrm{~B} 4$ & $*$ & $* *$ \\
$\mathrm{~B} 5$ & $* * *$ & $*$ \\
$\mathrm{~B} 6$ & $* *$ & $* *$ \\
$\mathrm{~B} 7$ & $*$ & $*$ \\
$\mathrm{~B} 8$ & $* * *$ & $* *$ \\
$\mathrm{~B} 9$ & $*$ & $*$ \\
$\mathrm{~B} 10$ & $* * *$ & $*$ \\
$\mathrm{~B} 11$ & $*$ & $* *$ \\
$\mathrm{~B} 12$ & $* * *$ & $* *$ \\
$\mathrm{~B} 13$ & $* *$ & $*$ \\
\hline
\end{tabular}

Indicates *, a significant trend at $\mathrm{P} \geq 0.05 ; * *$, a significant trend at $\mathrm{P} \geq 0.01 ; * *$, a significant trend at $\geq 0.001$

of seedling that can withstand unfavorable climatic conditions and/or competition with weeds, etc.

The association of the seed size with germinability and the initial growth of seedling is dependent on the plant species (Ambika et al 2014). Increased germination and initial growth of seedlings are mainly associated with greater reserve food in larger seeds (Willenborg et al 2005). In wheat, larger seeds achieved higher germination by $4 \%$ compared to small but the greatest influence was on the growth of seedlings ( $\mathrm{P} \geq 0.002)$ (Chaffai \& Louchichi 2013). And in the seed of oats increase in germination was the same (4\%, the average of five varieties) and was achieved from larger seeds, while depending on the variety, the germination varied more considerably (14\%) (Mut \& Akay 2010). Thus, our results are consistent with it (Table 2).

Seed dormancy is a form of biological adaptation that prevents germination on the plant itself (viviparia), as well as germination of seeds at an inconvenient time of year, when the seedlings
Table 5-Coefficients of simple correlations ( $r$ ) between germination and growthof seedlings in laboratory conditions and in the field of the varieties of oilseedrape for germination, and growth of seedlings $(n=36)$

\begin{tabular}{llll}
\hline Variety & $\begin{array}{l}\text { Germinability } \\
(\%)\end{array}$ & $\begin{array}{l}\text { Stem } \\
(\mathrm{cm})\end{array}$ & $\begin{array}{l}\text { Root } \\
(\mathrm{cm})\end{array}$ \\
\hline $\mathrm{B} 1$ & $* * *$ & $* *$ & $* * *$ \\
$\mathrm{~B} 2$ & $* *$ & $* * *$ & $* * *$ \\
$\mathrm{~B} 3$ & $* * *$ & $*$ & $* *$ \\
$\mathrm{~B} 4$ & $* * *$ & $* * *$ & $* *$ \\
$\mathrm{~B} 5$ & $* * *$ & $* * *$ & $*$ \\
$\mathrm{~B} 6$ & $* *$ & $* *$ & $* *$ \\
$\mathrm{~B} 7$ & $*$ & $*$ & $*$ \\
$\mathrm{~B} 8$ & $* * *$ & $* * *$ & $* * *$ \\
$\mathrm{~B} 9$ & $* * *$ & $*$ & $* *$ \\
$\mathrm{~B} 10$ & $* * *$ & $* * *$ & $* * *$ \\
$\mathrm{~B} 11$ & $* * *$ & $* *$ & $*$ \\
$\mathrm{~B} 12$ & $* * *$ & $* * *$ & $* * *$ \\
$\mathrm{~B} 13$ & $* *$ & $* *$ & $* * *$ \\
\hline
\end{tabular}

Indicates *, a significant trend at $\mathrm{P} \geq 0.05$; **, a significant trend at $\mathrm{P} \geq 0.01 ; * * *$, a significant trend at $\mathrm{P} \geq 0.001$

would not endure adverse environmental conditions (Bewley 1997).

The basic division of seed dormancy is on embryonic, where dormancy control is performed within the embryo itself, and the on the dormancy caused by a seed coat that is waterproof and impermeable to gases, as well as a division into primary and secondary dormancy or their combinations Baskin \& Baskin (2004). Regardless of the form of seed dormancy, it conditions the subsequent germination of the seed whose seedlings even in the already established crop in competition with the already developed plants are with little chance of contributing to the establishment of crops of agricultural cultures, and from the agronomic aspect in general the seed dormancy is undesirable.

Also in the rapeseed according to Rahman \& McVetty (2011) on the seed after harvest, dormancy is pronounced, which means that these seeds will not germinate, although they have ideal germinating conditions (Koornneef \& Karssen 1994). 
The color of the oilseed rape seeds is determined by genetics, where the yellow seed coat is desirable because these seeds are characterized by a higher oil and protein content as well as their better quality (Rahman et al 2010; 2011). According to Neubert et al (2003) between the color of the seed coat and the chemical composition as well as the seed formation of the rapeseed, there is a connection, and the seeds with a darker seed coat contain more flavonoids that condition the seed inactivity.This also may be the reason for the variability of germination oilseed rape varieties after different concentrations of $\mathrm{NaCl}$ (Uyanıket al 2014).
Seeds of different groups of plants (Cereals, Legumes, Oil crops, Miscellaneous crops) are highly variable for germination during the storage period (Nagel \& Börner 2010). For oily cultures, it is characteristic that, during seed storage, degradation of the lipids leads to degradation of the quality (Graham 2008). According to Debeaujon et al (2000), the anatomical material and color of the rapeseed seed coat affect germination during the storage period. In our tests, crucial for deterioration or even improvement of the seed germinability was the seed coat color (Tables 2 and 5). That can be brought into conjunction with higher oil content in seeds where the seed color is brighter (Rahman et al 2010; 2011).

Table 6- Application of the aging test to the seed of different sizes (C1-C3), colors (D1-D3) and age (E0-A1) of rape seedlings

\begin{tabular}{|c|c|c|c|c|c|c|c|c|c|}
\hline \multirow{2}{*}{ Variety } & \multicolumn{3}{|c|}{ Seed size } & \multicolumn{3}{|c|}{ Seed color } & \multicolumn{3}{|c|}{ Seed age } \\
\hline & $C 1$ & $C 2$ & C3 & D1 & D2 & D3 & EO & E1 & $E 2$ \\
\hline B1 & $45^{\text {a A }}$ & $43^{\mathrm{aA}}$ & $44^{\text {a A }}$ & $39^{\mathrm{aA}}$ & $44^{\mathrm{aA}}$ & $52^{\text {a } \mathrm{B}}$ & $62^{\mathrm{aA}}$ & $45^{\text {a B }}$ & $39^{\mathrm{ac}}$ \\
\hline B2 & $43^{\text {a A }}$ & $44^{\mathrm{aA}}$ & $45^{\mathrm{aA}}$ & $40^{\mathrm{aA}}$ & $46^{\mathrm{aAB}}$ & $56^{\text {a B }}$ & $58^{\text {a A }}$ & $48^{\text {a B }}$ & $36^{\mathrm{aC}}$ \\
\hline B3 & $46^{\mathrm{aA}}$ & $46^{\mathrm{aA}}$ & $45^{\mathrm{aA}}$ & $42^{\mathrm{aA}}$ & $47^{\mathrm{aA}}$ & $53^{\mathrm{a} \mathrm{B}}$ & $58^{\text {a A }}$ & $46^{\mathrm{a} \mathrm{B}}$ & $39^{\mathrm{aC}}$ \\
\hline B4 & $45^{\text {a A }}$ & $42^{\mathrm{aA}}$ & $43^{\mathrm{aA}}$ & $38^{\mathrm{aA}}$ & $44^{\mathrm{a} \mathrm{AB}}$ & $55^{\text {а в }}$ & $60^{\mathrm{aA}}$ & $47^{\mathrm{a} \mathrm{B}}$ & $39^{\mathrm{ac}}$ \\
\hline B5 & $44^{\mathrm{aA}}$ & $44^{\mathrm{aA}}$ & $42^{\mathrm{aA}}$ & $41^{\mathrm{aA}}$ & $47^{\mathrm{a} A \mathrm{~B}}$ & $56^{\mathrm{a} \mathrm{B}}$ & $61^{\mathrm{aA}}$ & $45^{\mathrm{a} \mathrm{B}}$ & $37^{\mathrm{aC}}$ \\
\hline B6 & $43^{\text {a A }}$ & $45^{\mathrm{aA}}$ & $44^{\mathrm{aA}}$ & $42^{\mathrm{aA}}$ & $48^{\mathrm{aAB}}$ & $55^{\text {a } \mathrm{B}}$ & $58^{\mathrm{aA}}$ & $48^{\text {a B }}$ & $39^{\mathrm{aC}}$ \\
\hline B7 & $44^{\mathrm{aA}}$ & $43^{\mathrm{aA}}$ & $44^{\mathrm{aA}}$ & $40^{\mathrm{aA}}$ & $46^{\mathrm{aAB}}$ & $54^{\text {a B }}$ & $59^{\mathrm{aA}}$ & $46^{\mathrm{a} \mathrm{B}}$ & $36^{\mathrm{ac}}$ \\
\hline B8 & $45^{\mathrm{aA}}$ & $46^{\mathrm{aA}}$ & $44^{\mathrm{aA}}$ & $38^{\mathrm{aA}}$ & $47^{\mathrm{a} \mathrm{B}}$ & $56^{\mathrm{aC}}$ & $62^{\mathrm{aA}}$ & $46^{\mathrm{aB}}$ & $38^{\mathrm{aC}}$ \\
\hline B9 & $46^{\mathrm{aA}}$ & $46^{\mathrm{aA}}$ & $44^{\mathrm{aA}}$ & $39^{\mathrm{aA}}$ & $45^{\mathrm{a} A \mathrm{~B}}$ & $52^{\text {a } \mathrm{B}}$ & $61^{\mathrm{aA}}$ & $48^{\text {a B }}$ & $36^{\mathrm{aC}}$ \\
\hline B10 & $45^{\text {a A }}$ & $44^{\mathrm{aA}}$ & $43^{\text {a A }}$ & $42^{\mathrm{aA}}$ & $45^{\mathrm{aA}}$ & $54^{\text {a B }}$ & $59^{\mathrm{aA}}$ & $46^{\mathrm{a} \mathrm{B}}$ & $38^{\mathrm{ac}}$ \\
\hline B11 & $43^{\mathrm{aA}}$ & $45^{\mathrm{aA}}$ & $42^{\mathrm{aA}}$ & $38^{\mathrm{aA}}$ & $44^{\mathrm{aAB}}$ & $56^{\mathrm{a} \mathrm{B}}$ & $60^{\mathrm{aA}}$ & $45^{\mathrm{a} \mathrm{B}}$ & $36^{\mathrm{ac}}$ \\
\hline B12 & $42^{\text {a A }}$ & $44^{\mathrm{aA}}$ & $43^{\mathrm{aA}}$ & $40^{\mathrm{aA}}$ & $46^{\mathrm{aAB}}$ & $52^{\mathrm{a} \mathrm{B}}$ & $61^{\mathrm{aA}}$ & $46^{\mathrm{a} \mathrm{B}}$ & $37^{\mathrm{ac}}$ \\
\hline B13 & $45^{\text {a A }}$ & $43^{\mathrm{aA}}$ & $44^{\mathrm{aA}}$ & $41^{\mathrm{aA}}$ & $44^{\mathrm{aA}}$ & $56^{\mathrm{a} \mathrm{B}}$ & $60^{\mathrm{aA}}$ & $48^{\text {a B }}$ & $38^{\mathrm{ac}}$ \\
\hline $\bar{X}$ & 44.3 & 44.2 & 43.6 & 40.0 & 45.6 & 54.4 & 59.9 & 46.5 & 37.5 \\
\hline
\end{tabular}

Tukey multiplex test $(\mathrm{P} \geq 0.05)$, small letters show the difference $a, b \ldots \mathrm{x}$ for the column, capital letters show the difference A, B...x, for the line

\section{Conclusions}

Higher seed germination of up to $3.6 \%$ is achieved from larger seed. Brighter seeds give higher germination after three months of seed preservation by $4 \%$. In contrast, the darker seed yields higher germination after fifteen months of storage for $11 \%$ and has a greater potential for preserving germinability after a long period of storage. The use of seeds with higher germinability leads to a higher growth in root and stem, as indicated by their correlative interdependence ( $r$ ) which is the most pronounced in the case of the following varieties: KVS Gordon, Jasna, Zlatna.

No clear difference was found between hybrid varieties (B1 to B9) and domestic varieties (B10-B13) for seed germinability and dormancy as 
well as the growth of seedlings. The obtained results can usefully serve farmers when choosing varieties for the establishment of rapeseed and/or growers when creating new varieties.

\section{Acknowledgements}

This research has been partof the national projects (No. TR 31092 and 31057), which were financed by the Ministry of Education, Science and Technological Development of Republic of Serbia.

\section{References}

Adkins S W, Bellairs S M \& Loch D S (2002). Seed dormancy mechanisms in warm-season grass species. Euphytica 126: 13-20

Ambika S, Manonmani V \& Somasundaram G (2014). Review onthe effect of seed size on seedling vigor and seed yield. Research Journal of Seed Science 7: 31-38

Avc1 S, İleri O \& Kaya D M (2017). Genotypic variation among Sorghum cultivars or seed vigor, salt anddrought Stresses. Tartm Bilimleri Dergisi-Journal of Agricultural Sciences 23: 335-343

Baskin J M \& Baskin C C (2004). A classification system for seed dormancy. Seed Science Research 14: 1-16

Bewley J D (1997). Seed germination and dormancy. Plant Cell 9: 1055-1066

Chaffai A \& Louchichi B (2013). Effect of seed size on germination and establishment of vigorous seedlings in durum wheat (Triticum durum Desf.). Advances in Environmental Biology 7: 77-81

Debeaujon I, Léon-Kloosterziel M K \& Koornneef M (2000). Influence of the testa on seed dormancy, germination, and longevity in Arabidopsis. Plant Physiology 122(2): 403-414

Graham I A (2008). Seed storage oil mobilization. Annual Review of Plant Biology 59: 115-142

Gu J, Chao H, Gan L, Guo L, Zhang K, Li Y, Wang H, Raboanatahiry N\& Li M (2016). Proteomic dissection of seed germination and seedling establishment in Brassica napus. Frontiers in Plant Science 7: 1482. doi: 10.3389/fpls.2016.01482

ISTA (2008). Biochemical test for viability: the topographical tetrazolium test. In: International Rules for Seed Testing. ISTA, Bassersdorf, Switzerland. pp. $1-30$
ISTA (2016). International Rules for Seed Testing, Bassersdorf

Kakhki H T, Kazemi M \& Tavakoli H (2008). Analysis of seed size effect on seedling characteristics of different types of wheat (Triticum aestivum L.) cultivars. Asian Journal of Plant Sciences 7: 666-671

Komba C G, Brunton J B \& Hampton G J (2006). Accelerated agingvigor testing of kale (Brassica oleracea L. var. acephala DC) seed. Seed Science and Technology 1: 205-208

Koornneef M \& Karssen M C (1994). Seed dormancy and germination. In: Meyerowitz EM, Somerville CR, (Eds) Arabidopsis, Cold Spring Harbor, NY: Cold Spring Harbor Laboratory Press. pp. 313-334

Liu A, Gao F, Kanno Y, Jordan M C, Kamiya Y, Seo M \& Ayele B T (2013). Regulation of wheat seed dormancy by after-ripening is mediated by specific transcriptional switches that induce changes in seed hormone metabolism and signaling. PLoS One 8(2): e56570. doi:10.1371/journal.pone.0056570

Mut Z \& Akay H (2010). Effect of seed size and drought stress on germination and seedling growth of naked oat (Avena sativa L.). Bulgarian Journal of Agricultural Science 16: 459-467

Nagel M \& Börner A (2010). The longevity of crop seeds stored under ambient conditions. Seed Science Research 20: 1-12

Neubert A B, Lühs W, Baetzel R \& Friedt W (2003). Influence of seed color on seed vigor in Brassica napus. InProceedings of the $11^{\text {th }}$ International Rapeseed Congress, 6-10 July 2003. Vol. 1. Edited by H. Sørensen. Dept. of Chemistry, The Royal Veterinary and Agricultural University, Frederiksberg, Denmark, pp. 253-256

Rahman M \& McVetty E B P (2011). Panorama de la couleur des graines de Brassica. Canadian Journal of Plant Science 91: 437-446

Rahman M, Li G, Schroeder D \& McVetty E B P (2010). Inheritance of seed coat color genes in Brassica napus (L.) and tagging the genesusing SRAP, SCAR and SNP molecular markers. Molecular Breeding 26: 439-453

Stanisavljević R, Đokić D, Milenković J, Đukanović L, Stevović V, Simić A \& Dodig D (2011). Seed germination and seedling vigor Italian ryegrass cocksfoot and timothy following harvest and storage. Ciencia Agrotecnologia 35: 1141-1148 
Stanisavljević R, Vučković S, Simić A, Marković J, Lakić Z, Terzić D \& Đokić D (2012). Acid and temperature treatments result in increased germination of seeds of three fescue species. Notulae Botanicae Horti Agrobotanici Cluj-Napoca 40: 220-226

Stanisavljević R, Velijević N, Štrbanović R, Postić D, Aleksić G, Trkulja N, Knežević J \& Dodig D (2018). Seed quality of vetch (Vicia sativa L.) affected by different seed colors and sizes after various storage periods. International Journal Agriculture and Biology 20: 2655-2660

Statistical Yearbook of Serbia (2017). Statistical office of the republic of Serbia, Belgrade, webrzs.stat.gov.rs/ WebSite/Public/PageView.aspx?pKey=82
Uyanık M, Kara Ş M \& Korkmaz K (2014). Bazı kışlık kolza (Brassica napus L.) çeşitlerinin çimlenme döneminde tuz stresine tepkilerinin belirlenmesi. Tartm Bilimleri Dergisi- Journal of Agricultural Sciences 20: 368-375

Willenborg C J, Wildeman J C, Miller A K, Rossnagel B G \& Shirtliffe S J (2005). Oat germination characteristics differ among genotypes, seed sizes and osmotic potential. Crop Science 45: 2023-2029

Zareian A, Hamidi A, Sadeghi H \& Jazaeri R M (2013). Effect of seed size on some germination characteristics, seedling emergence percentage and yield of three wheat (Triticum aestivum L.) cultivars in laboratory and field. Middle East Journal of Scientific Research 13: $1126-1131$ 